marred the church does not give an adequate expression of the Kingdom of God.

"The Memorial Supper" is likely to have a wide reading among Southern Baptists, and will doubtless also find many readers beyond the author's constituency; and, wherever read, will strengthen conservative conviction as to this ordinance, and will deepen the sense of its spiritual significance and value.

C. S. Gardner.

\title{
Baptist Opportunity.
}

By W. O. Carver, Th.D., Professor of Comparative Religion and Missions in the Southern Baptist Theological Seminary, Louisville Ky. American Baptist Publication Society, Philadelphia. Pp. 72, Price 15 cents.

The booklet opens with the following striking sentence: "Baptists have today the greatest opportunity in history." This sentence is an epitome of the book. The author finds in the "World Conditions", "The Religious Situation" and "The Baptist Situation" an unrivalled opportunity for Protestants in general and for Baptists in particular. The general awakening in Japan, China and elsewhere; the increasing individualism and sense of brotherhood; the gradual spread of religious freedom; the rise of Christianity into the standard by which other religions measure themselves; a world-wide revival of interest in religion ("It is twenty-five hundred years since the world was so universally interested in religion as it is today," p. 31) ; a growing demand for a simple Christianity, constitute the chief elements in the Baptist opportunity so far as world conditions are concerned.

To meet these conditions the Baptists have numbers, enlightenment, wealth; the unity and self-consciousness of a great lrotherhood, a sense of the imperialism of the kingdom of Christ and a new grip on the meaning of our doctrines and ordinances. The demands which this opportunity makes upon the denomination are first of all loyalty to spiritual truth, to the personal Christ, to the church as "the working organization in the kingdom of God", to the ordinances "as the pictured evangel", to the Gospel "as God's love message to a 
lost world", to the Bible "as the true record of the infallible Son"; and in the second place "fidelity to the waiting world". "The historical question of moment is not which denomination is prior, but which is primal."

The booklet is a spiritual tonic. It is not foolishly optimistic in prophetic note. It sees the past failures and acknowledges the present weaknesses and dangers of the Baptists, but it holds up before our eyes an opportunity that is a mighty call to heroic endeavor, and it believes the Baptists can meet the opportunity.

W. J. McGlothlin.

\section{The Cloud of Witnesses, and Other Semons.}

By Rev. J. B. Hawthorne, D.D. Sunday School Board, Southern Baptist Convention, Nashville, Tenn.

The past generation of Baptists has included no preacher superior to the author of this volume of sermons. Indeed, the author is of the present generation, although he insists upon referring to himself rather in the past tense. No man among us is more youthful in spirit or more optimistic in his view of life and the Kingdom of God.

Dr. Hawthorne has a remarkable command of the English language. His style is as clear as erystal. There is not a weak sentence in the book. These sermons exhibit clear thought, careful exegesis, and intense vigor of thought, feeling and expression. The first sermon in the volume, "The Cloud of Witnesses", is one of the most remarkable we have read. This sermon alone is worth far more than the cost of the volume. The sermons also on "Why We Should Serve and Honor all Men, Humility and Its Counterfeits", and various others are sermons of great power.

Dr. Hawthorne's career has been a knightly one. He has advocated every cause of righteousness; he has never wavered in his devotion to the highest ideals; he has been undaunted in his courage, and marvellously skillful and magnetic in his presentation of great truths to his generation. No wonder young men have been so enthusiastic over him, and have loved to hover in his shadow. As one reads these pages, he feels the propulsion of a great character and the urgency of an 